\title{
CARBOHYDRATE ENHANCED BIOFILM GROWTH IN ANAEROBIC FLUIDIZED BED REACTOR TREATING SYNTHETIC WASTEWATER
}

\section{EFEITO DA ADIÇÃO DE CARBOIDRATOS NO CRESCIMENTO DE BIOFILME EM REATOR ANAERÓBIO DE LEITO FLUIDIFICADO}

\section{Renata Medici Frayne Cuba ${ }^{1}$, Francisco Javier Cuba Teran ${ }^{2}$}

\author{
${ }^{1}$ Universidade do Oeste Paulista - Professora Doutora da Faculdade de Ciências e \\ Letras de Presidente Prudente - e-mail: renatamedici@unoeste.br \\ ${ }^{2}$ Universidade Estadual Paulista - Professor Doutor do Departamento de Física, \\ Química e Biologia da Faculdade de Ciências e Tecnologia de Presidente Prudente - \\ e-mail: fteran@fct.unesp.br
}

\begin{abstract}
Biofilm dynamics in anaerobic fluidized bed reactor was studied since start-up during a 600-day operation time. Specific methanogenic activity tests revealed gas production by the anaerobic biomass since $30^{\text {th }}$ operation day. Scanning Electron Microscopy (SEM) micrographs permitted to verify three bacterial development stages depending on the organic loading imposed to the system. Increasing of organic loading caused methanogenic specific activity depletion due to diffusion resistance through anaerobic biofilm. With maximum organic loading of $28.5 \mathrm{~kg}$ COD. $\mathrm{m}^{-3}$. day $^{-1}$, almost $10 \%$ of the volatile solids fixed in inert particle surface were detected as polymeric extracellular material.
\end{abstract}

Keywords: Anaerobic treatment. Biofilm. Fluidized bed. Synthetic sewage.

\section{RESUMO}

A dinâmica do biofilme em um reator anaeróbio de leito fluidificado foi estudada durante 600 dias desde a partida do sistema. Testes de atividade metanogênica específica revelaram produção de gás pela biomassa anaeróbia desde o trigésimo dia de operação. Microfotografias obtidas com microscópio eletrônico de varredura (MEV) permitiram verificar três estágios no desenvolvimento das bactérias, dependendo da carga orgânica imposta ao sistema. O aumento de carga 
orgânica causou a diminuição da atividade metanogênica específica devido à resistência à difusividade ao longo do biofilme anaeróbio. Com carga orgânica máxima de $28,5 \mathrm{~kg}$ COD. $\mathrm{m}^{-3} \cdot \mathrm{dia}^{-1}$, aproximadamente $10 \%$ dos sólidos voláteis aderidos na superfície das partículas inertes foi identificado como material polimérico extracelular.

Palavras-chave: Tratamento anaeróbio. Biofilme. Leito fluidificado. Esgoto sintético.

\section{INTRODUCTION}

Fixed film biological treatment of wastewater has been established for a long time, and the outstanding characteristics of adhesion of mixed cultures on common materials as sand, plastic and stone have been noticed everywhere. The fact of biomass development on inert material's surface has leaded to enhanced research directed towards the study of phenomena involved in this process. Particularly, anaerobic biofilms have been reported as formed principally by layers of bacterial consortia whose thickness depends on substrate concentration present in the reactor's bulk liquid.

Application of fluidized bed technology to study anaerobic biofilm development shows to be quite favorable in order to maintain integrity of bioparticles so one can make precise measurements of thickness and determinations of exopolymer composition and accumulation. Allied to these techniques, use of synthetic substrate, simulating sewage composition, permitted to achieve these purposes without the presence of hazardous pathogens.

The aim of this research was to take advantage of the favorable characteristic of fluidized bed reactor operation, in order to study the consequences of increasing organic loading on anaerobic biofilm development as well as biomass activity. Once obtained steady state, the pilot installation was operated under constant flow conditions, with variable organic loading due to the increase of sucrose concentration in synthetic sewage, witch allowed to attain favorable biofilm growth conditions in the system.

\section{METHODS}

Pilot scale system was disposed in a metallic ambience isolating metallic structure to maintenance constant temperature approximately $30^{\circ} \mathrm{C}$ during the experimental research time. Air heating facilities were also installed inside the structure, witch were composed by thermostat regulated heating resistance and fan. Water heater was also installed in the flow division basin to ensure constant influent temperature. 
Fluidized bed reactor consisted in 1,65 m acrylic tubular column with $8 \mathrm{~cm}$ intern diameter. On top of acrylic tube, a $20 \mathrm{~cm}$ diameter cylindrical phase separating unit was placed in order to carry out solid-liquid-gas separation. Initially the reactor was filled with approximately $90 \mathrm{~cm}$ of quartzitic sand with an effective size of 0,1 $\mathrm{mm}$ (density of 2,65 g. $\mathrm{cm}^{-3}$ ) witch was fluidized by $30 \mathrm{~L}^{-1} \mathrm{~h}^{-1}$ upflow synthetic sewage. Effluent withdrawal was accomplished from the flow division basin witch also received recirculating flow from the reactor. Figure 1 shows schematic diagram of pilot plant.

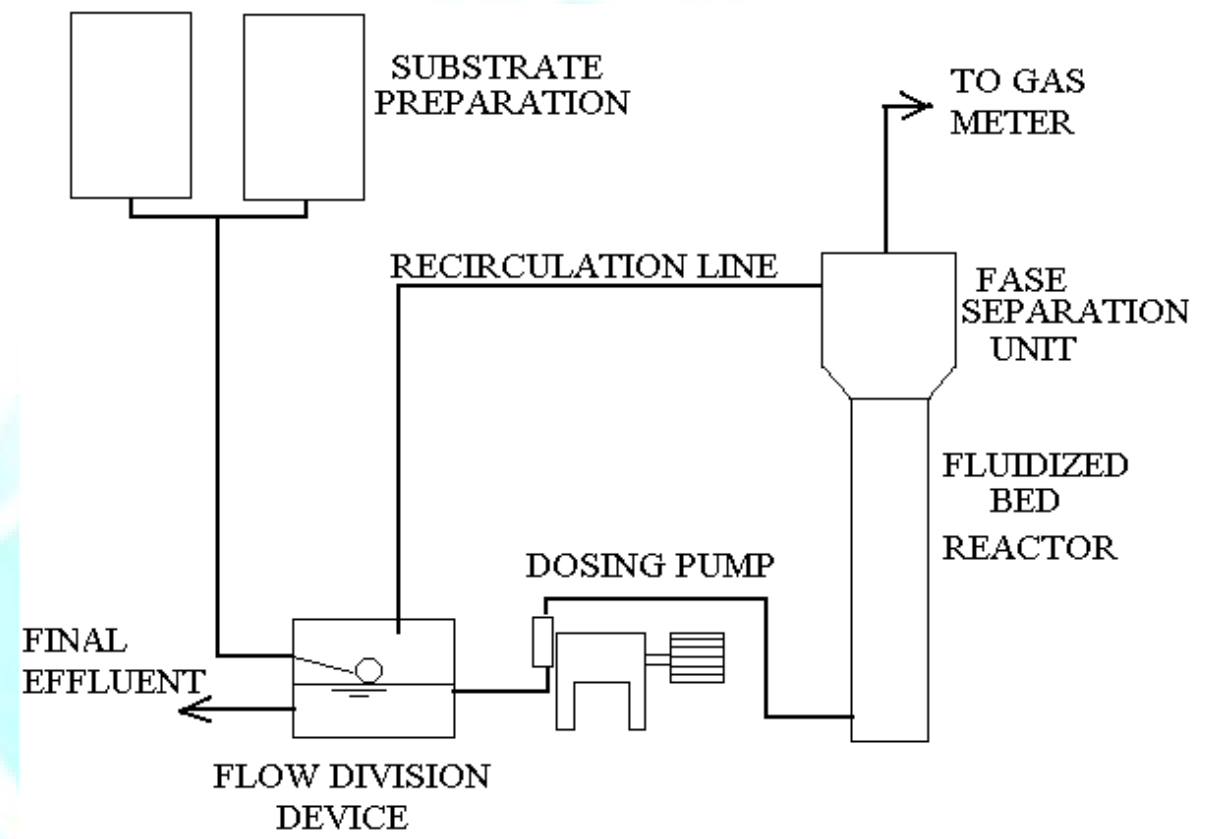

Figure 1. Schematic diagram of pilot plant

During start up, $10 \mathrm{~L}$ of anaerobic sludge from a UASB reactor were inoculated into the system. Synthetic sewage composition was based in literature (TORRES, 1992) with some modifications due to components availability. So, organic components were commercial beef extract; commercial sucrose; soybean oil and corn starch. Inorganic components were $\mathrm{NaCl} ; \mathrm{MgCl}_{2} \cdot 2 \mathrm{H}_{2} \mathrm{O} ; \mathrm{CaCl}_{2} \cdot 2 \mathrm{H}_{2} \mathrm{O}$; $\mathrm{FeSO}_{4} .7 \mathrm{H}_{2} \mathrm{O} ; \mathrm{CaCO}_{3} ; \mathrm{Na}_{2} \mathrm{~S}$ and $\mathrm{NaHCO}_{3}$.

Physical-chemical analyses were developed according to the Standard Methods for the Examination of Water and Wastewater $20^{\text {th }}$ ed. (APHA, 1998), and specific methanogenic activity tests were executed following methodology proposed by Dolfing and Bloemen (1985). Scanning electron microscopy (SEM) sample preparation method included glutaraldeide fixation, ethanol dewatering and hexametildizilasane drying proceeded by gold covering, following methodology proposed by Araujo et. al (2003). SEM Microscopy and Photomicrography were accomplished in Zeiss DSM 960 equipment. 


\section{RESULTS AND DISCUSSION}

Initial sucrose concentration in synthetic sewage was $160 \mathrm{mg} \cdot \mathrm{L}^{-1}$ contributing to maintain COD concentration in the range of $381-479 \mathrm{mg} . \mathrm{L}^{-1}$ Subsequent raises in sucrose concentration characterized each one of the 10 phases of experimental work. Limit value reached $4480 \mathrm{mg} . \mathrm{L}^{-1}$ (mean organic loading equal to $28,86 \mathrm{~kg}$ COD.m ${ }^{3} \cdot$ day $^{-1}$ ) by the $9^{\text {th }}$ phase of system operation. Higher organic loadings (OL) applied to the system caused depletion in COD removal efficiency and increase in biofilm thickness. By the time when OL reached maximum value of $34 \mathrm{~kg}$ COD.m ${ }^{-3}$.day ${ }^{-1}$, film thickness was near $300 \mu \mathrm{m}$ constituted of approximately $10 \%$ of polymeric material. Figure 2 presents a plot of biofilm thickness vs. operation time and OL variation is also presented. As showed in Figure 3, COD removal efficiency had a $10 \%$ depletion under this conditions.

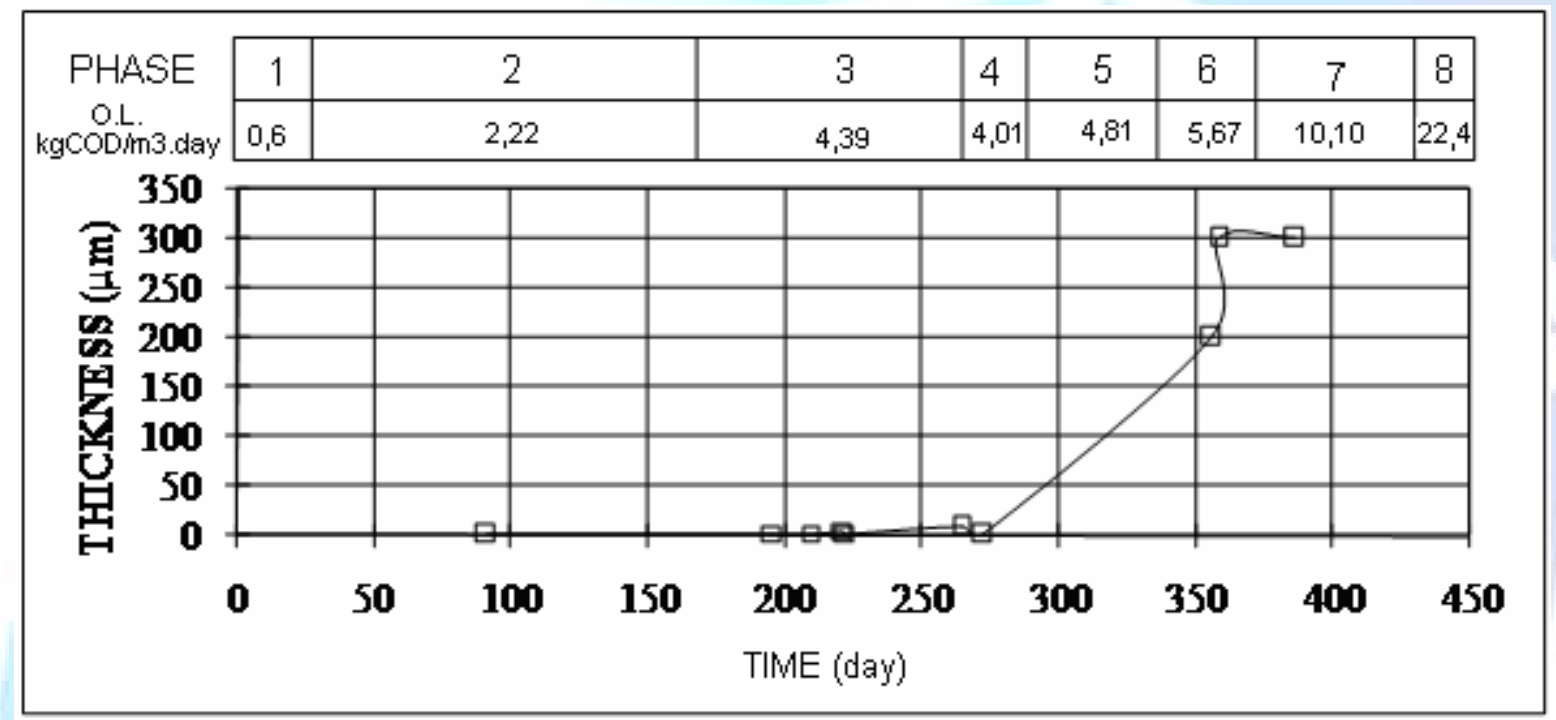

Figure 2. Biofilm thickness variation vs. operation time

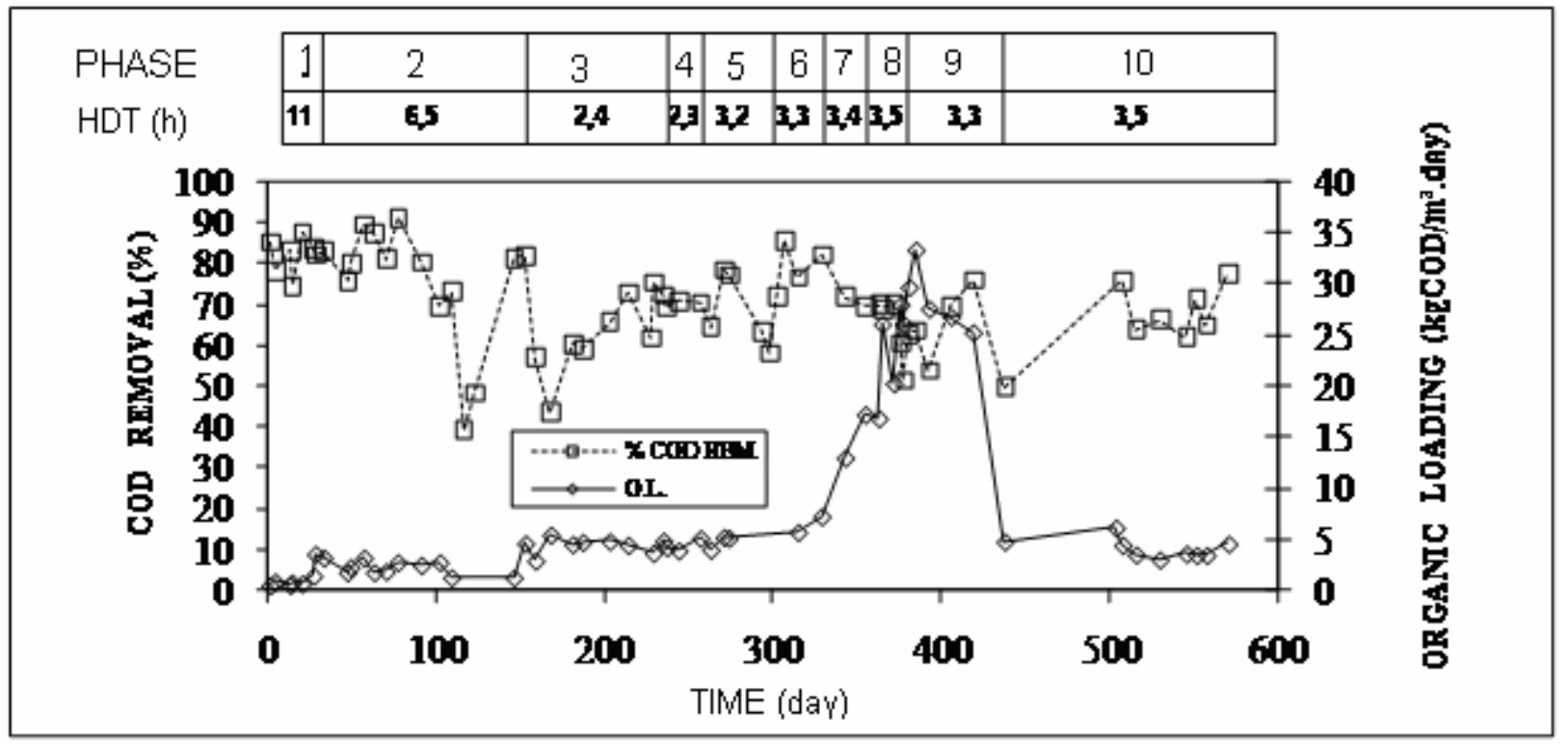

Figure 3. COD removal percentage and $\mathrm{OL}$ variation during experimental period 
Methanogenic specific activity was clearly affected by OL variations in the system; one can observe clear growth from phase 4, when sucrose concentration in the synthetic sewage began to be increased. Seven substrates were used to test methane production by samples of bioparticles, i. e. synthetic sewage, acetate, formiate, butirate, formiate, methanol e sucrose solutions. Test with synthetic sewage presented minor values of methanogenic activity since COD/VSS relation in this case was significantly lower than in other substrates. Diffusion resistance was evidenced from $9^{\text {th }}$ phase when depletion in methanogenic activity was detected and tests purposed by Araujo (1995) revealed exo-polymeric presence of near $10 \%$ of the total VSS concentration.

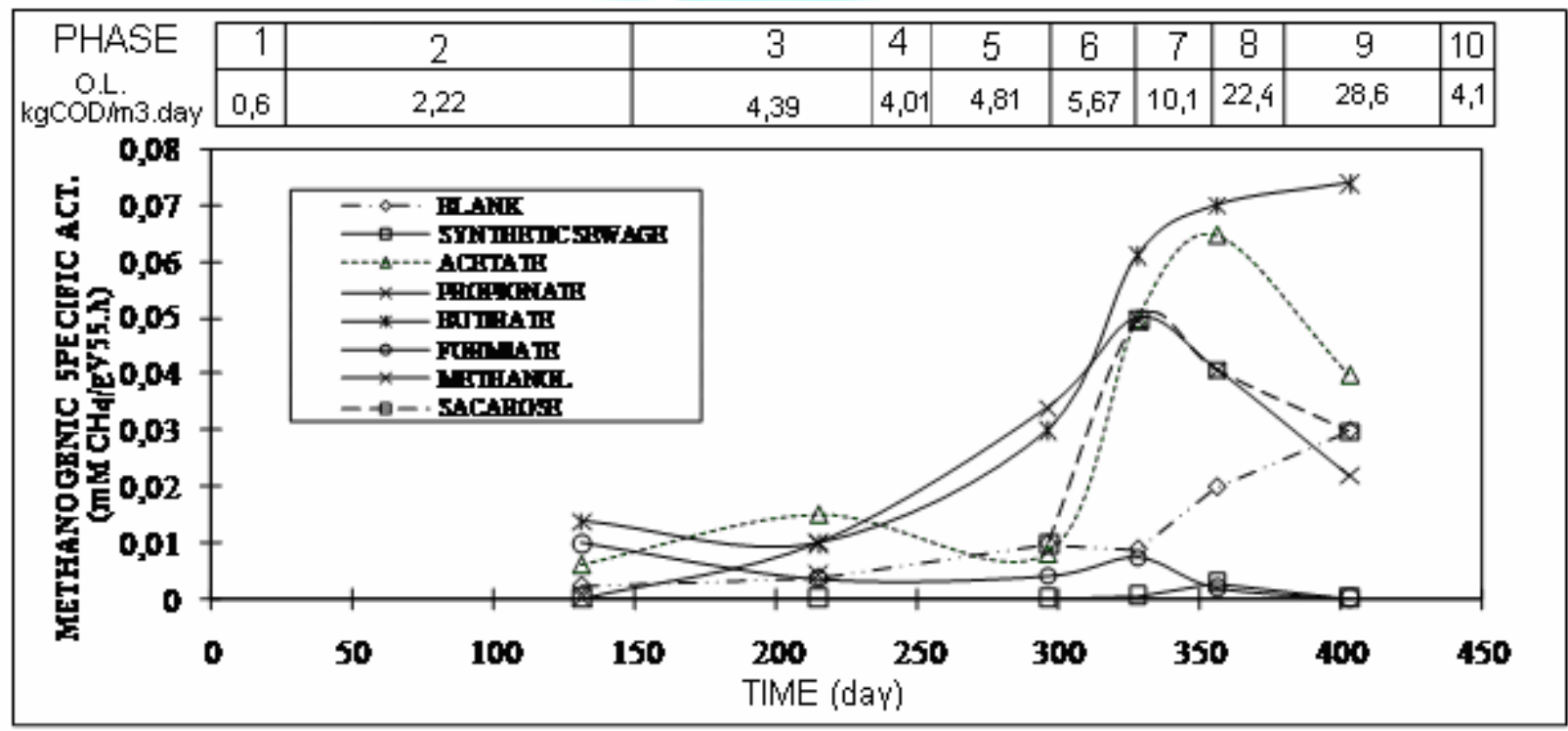

Figure 4. Methanogenic specific activity of bioparticle samples collected from reactor during operation period. Adapted from Araujo (1995).

Figures 5, 6 and 7 present three different stages in biomass development on inert particle surface. The 3D quality of photomicrographs permitted accurate biofilm thickness measurement. Figure 5 shows the beginning of phase 2 where minor quantity of methanogenic bacteria was noted. Long shaped Methanobrevibacter genera type bacteria were identified in this phase. In the second stage, filamentous methanogenic bacteria reminding Methanotrix soengenii morphology were present in appreciable quantities in bioparticle's subsurface in phase 6 , evidencing good methane production and higher values of methanogenic specific activity. Finally, third stage presented filamentous bacteria seemed immersed in great quantity of polymeric material witch cemented two or more bioparticles together forming $2 \mathrm{~cm}$ size aggregates as one can see after Figure 7. 


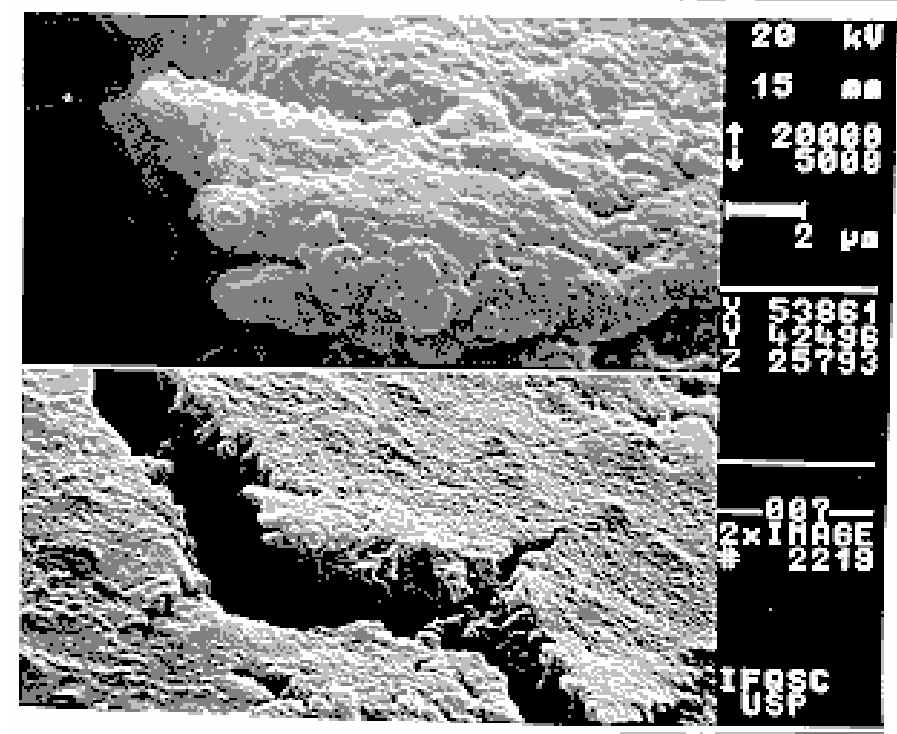

Figure 5. First stage biofilm surface photomicrography showing bacteria apparently immersed in polymeric matrix

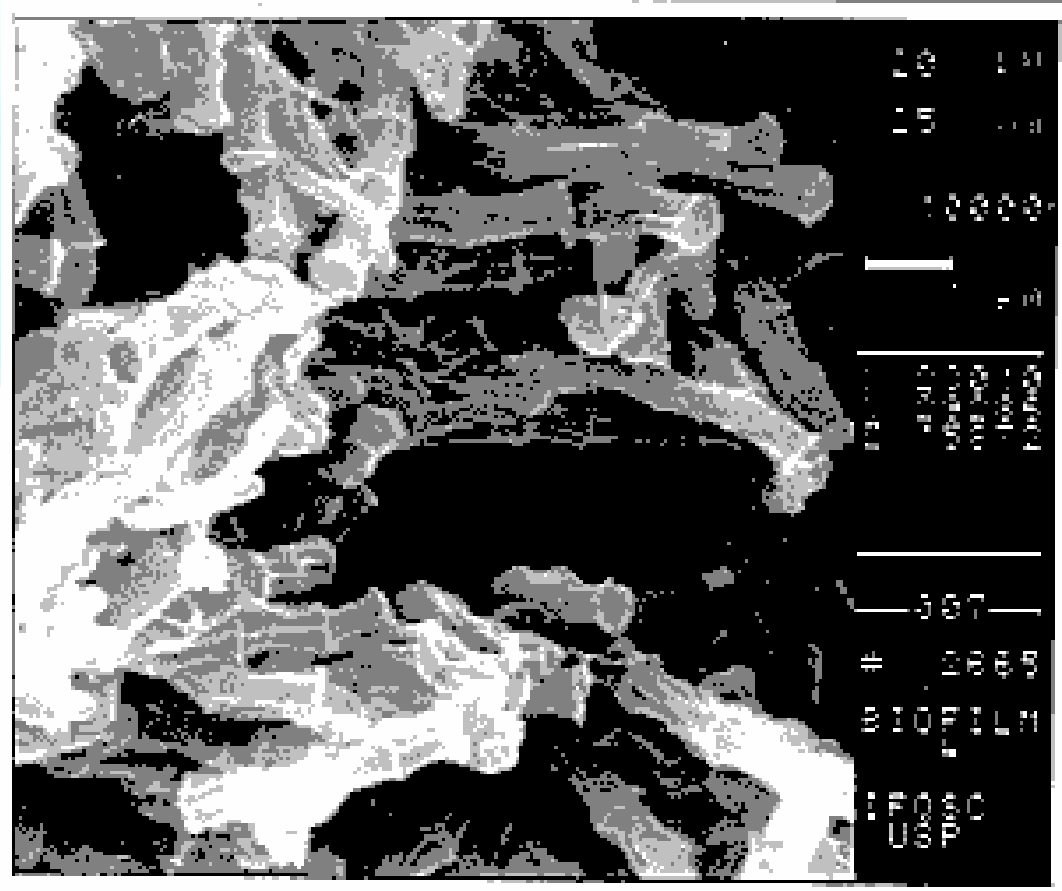

Figure 6. Second stage biofilm subsurface photomicrography showing Methanotrix soengenii type morphology bacteria 


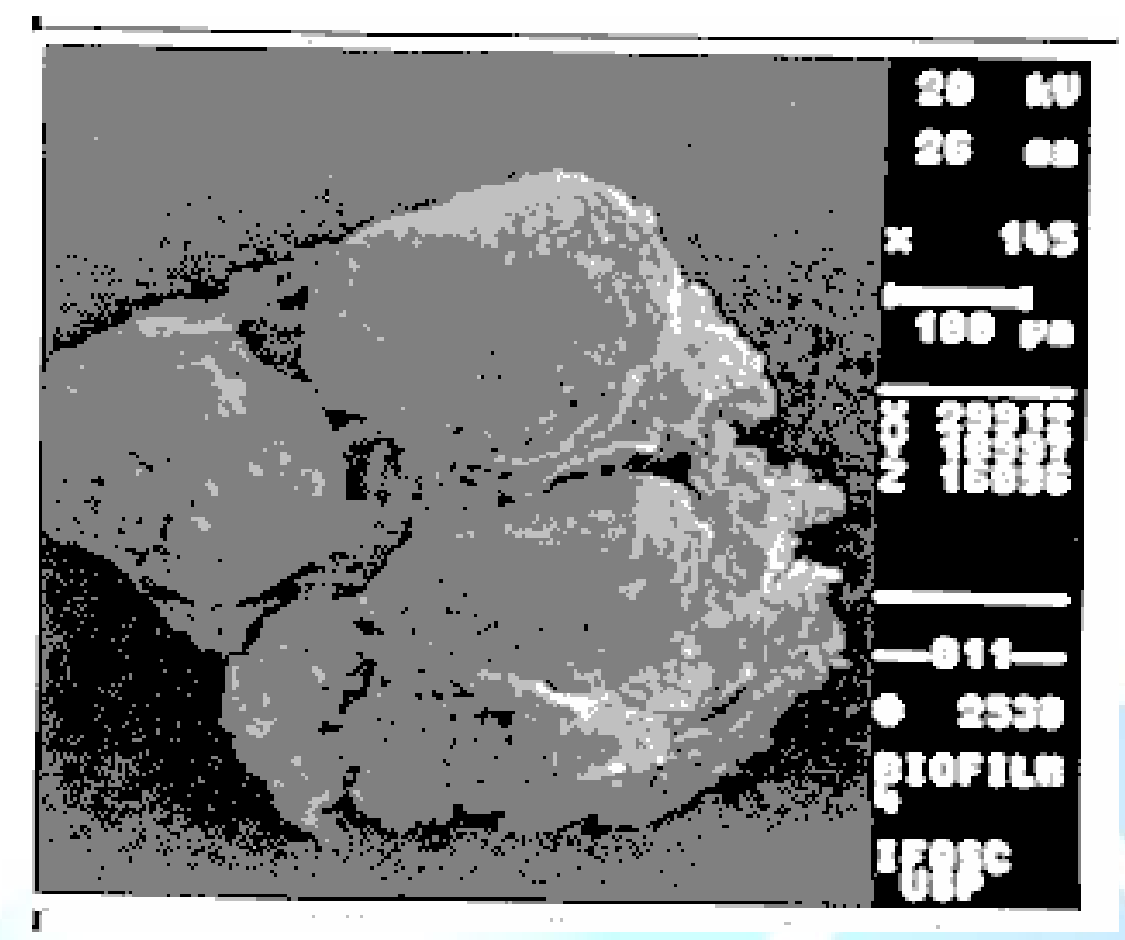

Figure 7. Third stage aggregate photomicrography showing $500 \mu \mathrm{m}$-size bioparticle aggregate

\section{CONCLUSIONS}

The work done so far has shown that the fluidized bed reactor represents an attractive alternative for biofilm development study since hydrodynamic characteristics seem to favor bioparticle integrity.

Raising organic loading in terms of increase of sucrose concentration in the synthetic sewage composition has the following effect on biomass:

- Increase in biofilm thickness;

- Accumulation of high concentrations of polymeric material;

- Raise in VSS/Polymeric material relation (nearly 10\% of VSS determined were polymeric material by phase 9 );

- Depletion in methanogenic specific activity;

- Depletion of COD removal efficiency due to increase in substract diffusion resistance through thick anaerobic biofilm;

- Diminishing in methanogenic type bacteria in biofilm composition.

\section{ACKNOWLEGMENTS}

The author wishes to acknowledge the Fundação de Amparo à Pesquisa do Estado de São Paulo for scholarships and financial support for the implantation of pilot system and physical-chemical analysis. 


\section{REFERENCES}

APHA-AMERICAN PUBLIC HEALTH ASSOCIATION. Standard methods for the examination of water and wastewater. 20 ed. Washington: American Public Health Association, AWWA, WPCF, 1998. 1569 p.

ARAUJO J. C. Caracterização e evolução do biofilme em reator anaeróbio de leito fluidificado alimentado com esgoto sintético. 1995. 233f. Dissertação (Mestrado em Hidráulica e Saneamento) Escola de Engenharia de São Carlos, Universidade de São Paulo.1995.

ARAUJO J.C. TERÁN F. J. C. CAMPOS J. R. VAZOLLER R. F. Comparison of hexamethyldisilazane and critical pointdrying treatments for SEM analysis of anaerobic biofilmsand granular sludge. Journal of Electron Microscopy, n.52, v.4, p. 429-43, 2003.

DOLFING, J.; BLOEMEN, W.G.B.M. Activity measurements as a tool to characterize the microbial composition of methanogenic environments. Applied Environmental Microbiology, n. 49, v.2, p.1142-1145. 1985.

TORRES, P. Desempenho de um reator anaeróbio de manta de lodo (UASB) no tratamento de substrato sintético simulando esgotos sanitários. 1992. 120f. Dissertação (Mestrado em Hidráulica e Saneamento) Escola de Engenharia de São Carlos, Universidade de São Paulo. 1992. 